\title{
Resveratrol attenuates hepatic complications associated with insulin resistance: Implications on hepatic HAIR, LAIR, cell energy and DNA fragmentation
}

\author{
Dalia O. Saleh, Sally A. El Awdan, Gehad A. Abdel Jaleel, Rania F. Ahmed \\ Department of Pharmacology, Medical division, National Research Centre, (ID: 60014618), Dokki, 12622, Giza, Egypt.
}

\begin{tabular}{|c|c|}
\hline ARTICLE INFO & ABSTRACT \\
\hline $\begin{array}{l}\text { Article history: } \\
\text { Received on: } 12 / 04 / 2017 \\
\text { Accepted on: } 18 / 06 / 2017 \\
\text { Available online: } 30 / 08 / 2017\end{array}$ & $\begin{array}{l}\text { Metabolic syndrome (MetS) is a chronic condition, often related to obesity, improper diet, insulin resistance } \\
\text { (IR); and can lead to significant health complications. Resveratrol (RSV) is a naturally occurring polyphenol } \\
\text { recently postulated to be a powerful antioxidant, hepatoprotective and a potential anti-hyperglycemic. Our } \\
\text { research aimed to investigate some possible mechanisms of action that may contribute to the efficacy of RSV to }\end{array}$ \\
\hline $\begin{array}{l}\text { Key words: } \\
\text { Adenylate energy charge; } \\
\text { DNA fragmentation; } \\
\text { Metabolic syndrome; } \\
\text { Resveratrol. }\end{array}$ & $\begin{array}{l}\text { high fructose (HFHF) diet model. Results revealed that RSV treatment ( } 40 \mathrm{mg} / \mathrm{kg} \text { p.o) for ten days protected } \\
\text { against IR and hepatic insult as demonstrated by reduction in HOMA-IR, hepatic HAIR and LAIR expression, } \\
\text { total cholesterol (TC), triglycerides (TG), TNF- } \alpha \text { levels, oxidative and nitrosative stresses, serum AST and } \\
\text { ALT. Furthermore; increasing serum albumin and total protein levels and improving hepatic tissue; cell energy } \\
\text { status by increasing adenylate energy charge (AEC) and reducing AMP/ATP ratio and preserving hepatic tissue } \\
\text { cellular integrity represented by lowering } 8 \text {-hydroxy-2-deoxyguanosine (8-OHDG); the results were comparable } \\
\text { to those of metformin. As a conclusion; using RSV could be valuable in treatment of hepatic complications } \\
\text { associated with MetS and its efficacy probably involves enhancement of cell energy as well as conservation of } \\
\text { cellular integrity. }\end{array}$ \\
\hline
\end{tabular}

\section{INTRODUCTION}

Metabolic syndrome (MetS) is considered as an important marker for subsequent development of type 2 diabetes mellitus (T2DM). It is characterized by multiple metabolic abnormalities, including obesity, hypertension, dyslipidemia, insulin resistance (IR), and impaired glucose tolerance. IR and the compensatory hyper-insulinemia are the hallmark of MetS; however, a number of other parameters appear to be related to MetS, including nonalcoholic fatty liver diseases (NAFLDs) (Liaw and Peplow, 2016, Martinez-Abundis et al., 2016). Liver is severely damaged in patients with diabetes mellitus (DM) and/or Mets. These damages include abnormal liver enzymes levels, necrosis, inflammation, cirrhosis, and hepatitis; leading to several nonalcoholic fatty liver diseases

* Corresponding Author

Rania F Ahmed, Department of Pharmacology, Medical division,

National Research Centre, (ID: 60014618), Dokki, 12622, Giza, Egypt.

E-mail: dr_rania_fouad @yahoo.com
(NAFLDs) (Mellendijk et al., 2015). NAFLDs include a spectrum of diseases, ranging from simple fatty liver to non-alcoholic steatohepatitis (NASH), which may progress to hepatocellular carcinoma (Lozano et al., 2016). NAFLD represents the hepatic manifestation of the destruction of the insulin networking and is often characterized by hepatic steatosis; associated with obesity, IR and MetS, which is accompanied by excessive hepatic lipids accumulation. (Bugianesi et al., 2010). There is an increasing evidence that insulin resistant states are accompanied by a lowgrade inflammation due to chronic activation of the innate immune system producing a relative excess of pro-inflammatory cytokines such as tumor necrosis factor- $\alpha$ (TNF- $\alpha$ ) and interlukin-6 (IL-6), both of which are produced by adipose tissue, thereby leading to an imbalance of pro-inflammatory and anti-inflammatory cytokines (Balistreri et al., 2010, Liaw and Peplow, 2016). Diet supplements including antioxidants, polyunsaturated fatty acids and mineral elements support IR treatment due to their antioxidant and antiinflammatory properties. 
Moreover, it is considered that a healthy balanced diet enriched with various diet supplements may be the best approach in NAFLD treatment (Sicinska et al., 2015).

Resveratrol (RSV) (3,5,4'-trihydroxystilbene) is a phytoalexin that has been detected in many fruits such as grapes, peanuts and the roots of the Asian plant Polygonum cuspidatum (Peredo-Escarcega et al., 2015).RSV was reported to be one of the most powerful nutraceuticals working as an anti-inflammatory and antioxidant as well as hepatoprotective (Chen et al., 2016, Pektas et al., 2016, Radwan and Ahmed, 2016) and recently it has been used as a protective agent against obesity and/or metabolic diseases for example hepatic steatosis and IR; yet results obtained from several studies are still debatable and its exact mechanism of action is still under investigation (Bremer, 2014, Peredo-Escarcega et al., 2015, Vallianou et al., 2013).

High fructose consumption is associated with metabolic disorders including IR and dyslipidemia as well as hepatic steatosis (Morsy et al., 2016). Animal intake of high amounts of fructose and fat is likely to lead to a constellation of abnormalities including IR, hypertriglyceridemia and obesity that mimic human metabolic syndrome. Furthermore; it has been documented that high fat, high fructose diet (HFHF diet) caused enhanced production of free radicals and reduced the antioxidants levels, thereby creating a redox imbalance which eventually results in oxidative stress (Lozano et al., 2016, Maithili Karpaga Selvi et al., 2015, Narasimhan et al., 2015, Rodriguez Lanzi et al., 2016).

The current research aimed to investigate some of the possible mechanisms involved in the efficacy of RSV against IR and hepatotoxic side effects resulting from MetS experimentally induced in rats using HFHF-diet model.

\section{MATERIAL AND METHODS}

\section{Animals}

Juvenile male albino rats weighing $80-90 \mathrm{~g}$ purchased from the animal house at the National Research Centre (NRC, Cairo, Egypt). Upon arrival; the animals were acclimatized for 7 days to a quiet colony room, with controlled ambient temperature $\left(22 \pm 1{ }^{\circ} \mathrm{C}\right)$ and a 12 hour natural light/dark cycle, housed eight per cage, fed a standard diet and water was provided ad lib. The experiments were performed with 8 rats per treatment group according to a randomized schedule. All experiments were performed according to the National Regulations on Animal Welfare and Institutional Animal Ethical Committee (IAEC).

\section{Drugs}

Trans-resveratrol; given as a generous gift from Jing Tea LLC (Australia), as Harmoni-T micronized transresveratrol capsules for ingestion. The powder in the capsules was freshly suspended in distilled water just before oral administration. Metformin hydrochloride tablets purchased from Cid Company (Egypt).Tablets were freshly ground and suspended in distilled water just before oral administration.

\section{Experimental design \\ High fat high fructose insulin resistance model}

Rats were weighed and insulin resistance (IR) was induced by adding high-fat diet $(60 \mathrm{kcal} / 100 \mathrm{kcal}$ saturated fat) with $20 \%$ fructose in the drinking water for 60 days (Axelsen $e t$ al., 2010). A group of 8 rats was used to serve as normal control; kept under the same conditions, fed a standard diet and water was provided ad lib. On day 59 rats were fasted over night for $12 \mathrm{hrs}$ except for drinking water (tap water was used for all groups on that night). On Day 60, random rats were chosen from each cage, IR was confirmed by measuring fasting glucose and insulin and by computing fasting insulin sensitivity indices HOMA-IR. At that time; a well-established and permanent IR animal model was present. Starting day 61; all groups except the normal control were daily orally administered their corresponding treatments concomitantly with the high fat high fructose (HFHF) diet. HFHF diet-induced insulin resistant rats were allocated to four groups and were treated as follows: group (1): HFHF control; receiving distilled water (5ml/kg; p.o daily), group (2): Metformin standard group; Metformin standard group; receiving metformin (150 mg/kg; p.o daily), group (3): R20 group; receiving RSV (20 $\mathrm{mg} / \mathrm{kg}$; p.o daily), group (4): R40 group; receiving RSV (40 $\mathrm{mg} / \mathrm{kg}$; p.o daily). All treatments were given for 10 consecutive days. In addition, the normal control received daily $(5 \mathrm{ml} / \mathrm{kg}$ distilled water p.o). After the last treatment, rats were fasted over night for $12 \mathrm{hrs}$ except for drinking water (tap water was used for all groups on that night). Twenty four hours after the last drugs ingestions; rats were weighed and blood samples were collected. Rats were then sacrificed and liver tissues were isolated and kept at $-80^{\circ} \mathrm{C}$ for further analyses.

\section{Biochemical assessments}

\section{Determination of serum fasting levels of glucose, Insulin and calculation of HOMA-IR}

Serum glucose level was determined spectrophotometrically (Trinder, 1969) and the concentration was expressed as $\mathrm{mg} / \mathrm{dl}$. Serum insulin level was determined by ELISA kit(Sceti Medical Lab K.K, Tokyo, Japan) the concentration was expressed as $\mu \mathrm{IU} / \mathrm{ml}$ (Grassi and Pradelles, 1991). Homeostatic Model Assessment-Insulin Resistance (HOMA-IR) was calculated as follows:

HOMA-IR $=$ [Fasting glucose $(\mathrm{mg} / \mathrm{dl}) / 18 *$ Fasting insulin $(\mu \mathrm{IU} / \mathrm{ml})] / 22.5$ (Matthews et al., 1985).

\section{Determination of liver tissue high affinity and low affinity insulin receptors (HAIR \& LAIR) expression.}

HAIR and LAIR were measured using radioimmunoassay as previously described (Corin and Donner, 1982).

\section{Determination of hepatic triglycerides and total cholesterol}

Hepatic triglycerides (TG) and total cholesterol (TC) were measured spectrophotometrically(Fassati,Principe, 1982, Richmond, 1973). 


\section{Determination of serum total protein, albumin, ALT and AST levels}

Serum total protein, albumin, aspartate aminotransferase (AST), alanine aminotransferase (ALT) levels were measured spectrophotometrically (Doumas et al., 1971, Gornall et al., 1949, Reitman,Frankel, 1957).

\section{Determination of liver tissue level of GSH, MDA and NOx}

Hepatic level of MDA was measured spectrophotometrically (Ruiz-Larrea et al., 1994) and similarly; GSH was measured spectrophotometrically using the method of Ellman (Ellman, 1959) modified by bulaj et al.(Bulaj et al., 1998). Hepatic nitric oxide (NOx) products (nitrates and nitrites) levels were determined using ELISA reader.(Miranda et al., 2001)

\section{Determination of liver tissue level of tumor necrosis factor alpha $(\mathrm{TNF}-\alpha)$}

The tissue level of tumor necrosis factor alpha (TNF- $\alpha)$ was determined with ELISA kit (Raybiotech) (Bonavida, 1991).

\section{Determination of liver tissue level of 8-OHDG}

Isolation and hydrolysis of liver DNA was performed using the method of Lodovici et al.(Lodovici et al., 1997). The hydrolyzed mixture was centrifuged and the supernatant were injected into the HPLC. The separation of 8-OHDG was performed with an Agilent HP 1200 series HPLC apparatus (USA). The analytical column was Supelcosil C18 (5 $\mu \mathrm{m}$ particle and $80 \mathrm{~A}^{\circ}$ pore size) $(250 \times 4.6 \mathrm{ID})$. The eluting solution was $\mathrm{H}_{2} \mathrm{O} /$ methanol at a ratio $(85: 15)$ with $50 \mathrm{mM} \mathrm{KH}_{2} \mathrm{PO}_{4}, \mathrm{pH} 5.5$ at a flow rate of $0.68 \mathrm{ml} / \mathrm{min}$. the $\mathrm{UV}$ detector was set at $245 \mathrm{~nm}$. The resulting chromatogram identified the concentration from the sample as compared to that of the standard purchased from Sigma Aldrich.

\section{Determination of liver tissue ATP, ADP and AMP}

The determination of tissue ATP, ADP and AMP was performed with an Agilent HP 1200 series HPLC apparatus
(USA). The analytical column was Ultrasphere ODS EC 250 x 4.6 $\mathrm{mm}$ column. Mobile phase A consisted of $0.06 \mathrm{~mol} / 1 \mathrm{~K}_{2} \mathrm{HPO}_{4}$ and $0.04 \mathrm{~mol} / 1 \mathrm{KH}_{2} \mathrm{PO}_{4}$ dissolved in deionized water and adjusted to pH 7.0 with $0.1 \mathrm{~mol} / 1 \mathrm{KOH}$, while mobile phase B consisted of $100 \%$ acetonitrile. Flow rate of the mobile phase was $1.2 \mathrm{ml} / \mathrm{min}$. the UV detector was set at $254 \mathrm{~nm}$. ATP, ADP and AMP in the samples were identified by comparison with standards purchased from Sigma Aldrich (Liu et al., 2006, Teerlink et al., 1993).

Total adenylate energy charge (AEC) was calculated according to the equation:

$$
\mathrm{AEC}=(\mathrm{ATP}+0.5 \mathrm{ADP}) /(\mathrm{ATP}+\mathrm{ADP}+
$$

AMP)(Atkinson, Walton, 1967).

\section{Statistical analyses}

Statistical analyses were carried out using one way ANOVA followed by Tukey's multiple comparisons test. $\mathrm{P}<0.05$ was accepted as being significant in all types of statistical tests. Graph prism software (version 6) was used to carry out all statistical tests. Values were expressed as means \pm S.E.

\section{RESULTS}

\section{Effects of RSV on body weight and metabolic parameters of rats with HFHF diet-induced IR}

HFHF showed an elevation the in the body weight as compared to the normal control. Treatment of rats with RSV dose dependently reduced body weight as compared to the HFHF group. Moreover; HFHF was associated with an elevation in the serum fasting glucose and insulin levels as well as HOMA-IR as compared to the normal control. Treatment with RSV dose dependently reduced glucose and insulin levels and HOMA-IR as compared to the HFHF control and the results of the higher dose were comparable to those of metformin. In addition; rats fed with HFHF diet showed significant elevation in liver tissue TG and TC levels as compared to the normal control. Treatment with RSV dose dependently reduced TG level significantly as compared to the HFHF control and furthermore; normalized TC level (Table 1).

Table 1: Effects of RSV on body weight and metabolic parameters of rats with HFHF diet-induced IR.

\begin{tabular}{|c|c|c|c|c|c|c|}
\hline Groups & Body weight (g) & $\begin{array}{c}\text { Serum glucose } \\
\mathrm{mg} / \mathrm{dl}\end{array}$ & $\begin{array}{c}\text { Serum insulin } \\
\mu \mathrm{IU} / \mathrm{ml}\end{array}$ & HOMA-IR & $\begin{array}{c}\text { Hepatic TG } \\
\text { mg/g tissue }\end{array}$ & $\begin{array}{l}\text { Hepatic TC } \\
\text { mg/g tissue }\end{array}$ \\
\hline Normal & $107.40 \pm 3.58^{*}$ & $62.63 \pm 1.13^{*}$ & $1.58 \pm 0.06^{*}$ & $0.23 \pm 0.01^{*}$ & $142.3 \pm 6.03^{*}$ & $15.87 \pm 0.75^{*}$ \\
\hline HFHF & $192.80 \pm 5.78^{\#}$ & $94.82 \pm 1.56^{\#}$ & $16.78 \pm 0.45^{\#}$ & $3.94 \pm 0.16^{\#}$ & $309.9 \pm 22.19^{\#}$ & $34.32 \pm 1.09^{\#}$ \\
\hline Metformin & $142.00 \pm 3.21^{* \#}$ & $67.13 \pm 2.04^{*}$ & $5.51 \pm 0.17^{* \#}$ & $0.92 \pm 0.05^{* \#}$ & $150.8 \pm 6.92^{*}$ & $21.57 \pm 1.07^{* \#}$ \\
\hline R20 & $169.40 \pm 2.99^{* \#}$ & $82.3 \pm 1.34^{* \#}$ & $9.46 \pm 0.26^{* \#}$ & $1.93 \pm 0.07^{* \#}$ & $206.2 \pm 11.47^{* \#}$ & $17.4 \pm 0.68^{*}$ \\
\hline R40 & $155.00 \pm 3.06^{* \#}$ & $68.38 \pm 2.17^{*}$ & $5.61 \pm 0.18^{* \#}$ & $0.95 \pm 0.05^{* \#}$ & $205.9 \pm 12.22$ *\# & $16.06 \pm 0.20$ * \\
\hline
\end{tabular}

*Significantly different from HFHF control, \# significantly different from normal control at $\mathrm{p}<0.05$. 


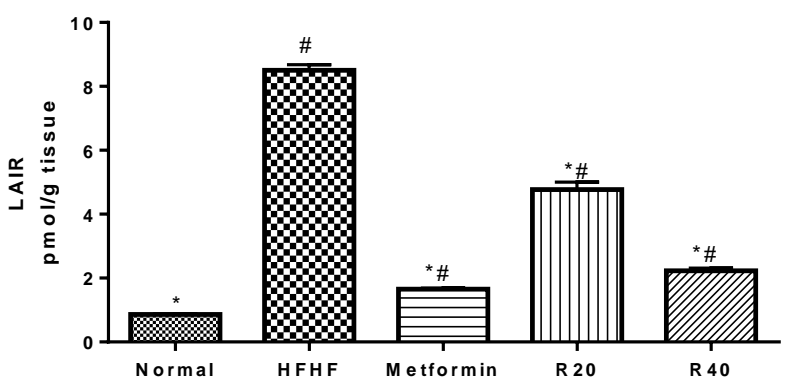

A

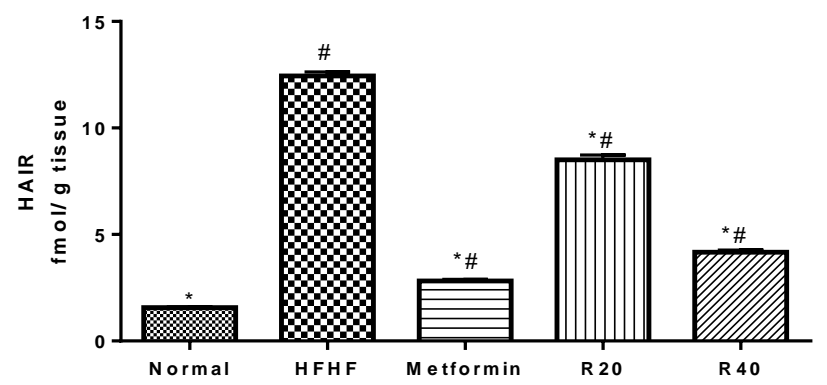

Fig. 1: Effects of RSV on hepatic LAIR (a) and HAIR (b) expression in rats with HFHF diet-induced IR. *Significantly different from HFHF control, \# significantly different from normal control at $\mathrm{p}<0.05$.

Table 2: Effect of RSV on serum ALT, AST, albumin and total protein in rats with HFHF diet-induced IR.

\begin{tabular}{|c|c|c|c|c|}
\hline Groups & $\begin{array}{c}\text { ALT } \\
\mathbf{u} / \mathbf{l}\end{array}$ & $\begin{array}{c}\text { AST } \\
\mathbf{u} / \mathbf{l}\end{array}$ & $\begin{array}{c}\text { Albumin } \\
\text { mg/dl }\end{array}$ & $\begin{array}{c}\text { Total protein } \\
\text { mg/dl }\end{array}$ \\
\hline Normal & $24.66 \pm 0.99^{*}$ & $133.34 \pm 3.29^{*}$ & $4.57 \pm 0.16^{*}$ & $7.79 \pm 0.30^{*}$ \\
\hline HFHF & $88.92 \pm 4.56^{\#}$ & $202.67 \pm 7.48^{\#}$ & $3.61 \pm 0.04^{\#}$ & $5.49 \pm 0.34^{\#}$ \\
\hline Metformin & $52.20 \pm 1.61^{\text {*\# }}$ & $170.77 \pm 10.16^{* \#}$ & $3.82 \pm 0.06^{\#}$ & $7.40 \pm 0.23^{*}$ \\
\hline $\mathbf{R 2 0}$ & $75.61 \pm 2.79^{* \#}$ & $191.33 \pm 3.88^{\#}$ & $4.23 \pm 0.16^{*}$ & $7.48 \pm 0.63^{*}$ \\
\hline R40 & $48.91 \pm 4.03^{* \#}$ & $160.68 \pm 2.42^{* \#}$ & $4.28 \pm 0.16^{*}$ & $7.66 \pm 0.65$ * \\
\hline
\end{tabular}

*Significantly different from HFHF control, \# significantly different from normal control at $\mathrm{p}<0.05$.

Table 3: Effects of RSV on hepatic oxidative and nitrosative stresses biomarkers in rats with HFHF diet-induced IR

\begin{tabular}{|c|c|c|c|}
\hline Groups & $\begin{array}{l}\text { GSH } \\
\text { ug/g }\end{array}$ & $\begin{array}{c}\text { MDA } \\
\mathrm{nmol} / \mathrm{g}\end{array}$ & $\begin{array}{c}\text { NOx } \\
\text { umol/g }\end{array}$ \\
\hline Normal & $29.12 \pm 1.116^{*}$ & $113.20 \pm 3.25^{*}$ & $19.39 \pm 0,78^{*}$ \\
\hline HFHF & $23.00 \pm 0.48^{\#}$ & $208.7 \pm 1.24^{\#}$ & $88.58 \pm 4.74^{\#}$ \\
\hline Metformin & $26.45 \pm 0.52^{* \#}$ & $122.8 \pm 5.70^{*}$ & $59.56 \pm 3.18^{* \#}$ \\
\hline $\mathrm{R} 20$ & $26.05 \pm 0.29^{\text {*\# }}$ & $161.1 \pm 11.8^{* \#}$ & $70.57 \pm 1.54^{* \#}$ \\
\hline R40 & $26.3 \pm 0.25^{* \#}$ & $154.1 \pm 4.49^{* \#}$ & $53.30 \pm 2.22^{* \#}$ \\
\hline
\end{tabular}

*Significantly different from HFHF control, \# significantly different from normal control at $\mathrm{p}<0.05$.

Effects of RSV on hepatic LAIR and HAIR expression in rats with HFHF diet-induced IR

Induction of IR by feeding rats with HFHF diet showed a marked increase in the expression of hepatic LAIR and HAIR in liver tissue $(8.51 \pm 0.17$ vs. $0.86 \pm 0.02 \mathrm{pmol} / \mathrm{g}$ and $12.45 \pm 0.18$ vs. $1.57 \pm 0.03 \mathrm{fmol} / \mathrm{g}$ ) respectively as compared to the normal control. Oral treatment of rats with $\operatorname{RSV}(20$ and $40 \mathrm{mg} / \mathrm{kg}$; p.o.) reduced the expression of hepatic LAIR $(4.77 \pm 0.23$ and $2.23 \pm 0.08$ vs. $8.51 \pm 0.17 \mathrm{pmol} / \mathrm{g})$ and HAIR $(8.51 \pm 0.22$ and $4.17 \pm 0.09$ vs. $12.45 \pm 0.18 \mathrm{fmol} / \mathrm{g}$ ) in a dose dependent manner as compared to HFHF control group.

This modulatory effect was comparable to those of metformin (Figure 1).

\section{Effect of RSV on serum ALT, AST, albumin and total protein in rats with HFHF diet-induced IR}

High fat high fructose diet-induced IR significantly increased serum ALT and AST as compared to the normal control. Treatment of rats with RSV showed a prominent decrease in serum ALT and AST contents as compared to the HFHF control and the results were comparable to those of metformin. Similarly, HFHF diet-induced IR significantly decreased serum albumin and total protein as compared to the normal control. Treatment of rats with
RSV elevated serum albumin and total protein in dose dependent manner as compared to the HFHF control and moreover: the results were more prominent over those of metformin (Table 2).

\section{Effects of RSV on hepatic oxidative and nitrosative stresses biomarkers in rats with HFHF diet-induced IR}

HFHF significantly decreased liver GSH and significantly increased liver MDA and NOx levels as compared to the normal control. Treatment of rats with RSV reduced liver MDA and NOx levels as compared to the HFHF control. Moreover; RSV significantly elevated liver GSH content and the results were comparable to those of metformin (Table 3 ).

\section{Effects of RSV on liver level of TNF- $\alpha$ in rats with HFHF diet induced IR}

Induction of IR was accompanied with a marked increase in hepatic TNF- $\alpha$ content $(641.1 \pm 10.82 v s .425 .9 \pm 10.36 \mathrm{pg} / \mathrm{g}$ tissue) as compared to the normal control $P<0.05$. Treatment with both metformin and RSV (20 $\mathrm{mg} / \mathrm{kg})$ resulted in significant reduction in the TNF- $\alpha$ level as compared to the HFHF group $(585.8 \pm 13.69$ and $579.1 \pm 7.836$ vs. $641.1 \pm 10.82 \mathrm{pg} / \mathrm{g}$ tissue $)$ at $P<0.05$. On the other hand, RSV $(40 \mathrm{mg} / \mathrm{kg}$ ) normalized TNF- $\alpha$ level (Figure 2). 


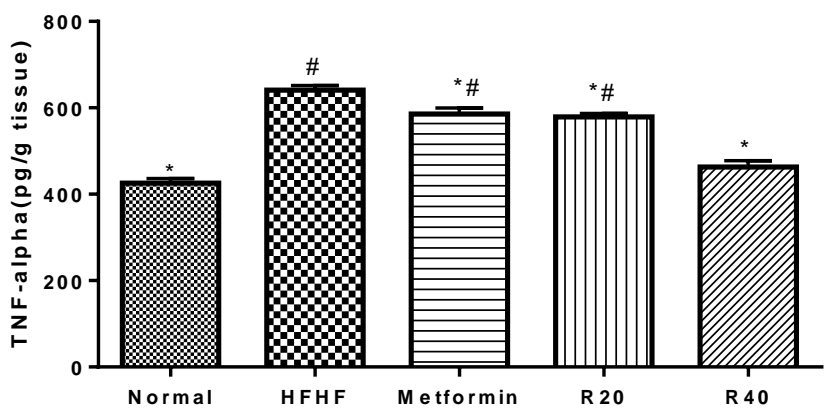

Fig. 2: Effects of RSV on liver level of TNF- $\alpha$ in rats with HFHF diet-induced IR. *Significantly different from HFHF control, \# significantly different from normal control at $\mathrm{p}<0.05$.

Table 4: Effects of RSV on liver tissue cell energy in rats with HFHF diet-induced IR.

\begin{tabular}{cccccc}
\hline Groups & $\begin{array}{c}\text { ATP } \\
\text { ug/g tissue }\end{array}$ & $\begin{array}{c}\text { ADP } \\
\text { ug/g tissue }\end{array}$ & $\begin{array}{c}\text { AMP } \\
\text { ug/g tissue }\end{array}$ & AEC & AMP/ATP \\
\hline Normal & $56.11 \pm 0.92^{*}$ & $31.82 \pm 1.18^{*}$ & $24.05 \pm 1.02^{*}$ & $0.643 \pm 0.007^{*}$ & $0.43 \pm 0.022^{*}$ \\
HFHF & $25.66 \pm 0.28^{\#}$ & $14.95 \pm 0.27^{\#}$ & $14.49 \pm 0.77^{\#}$ & $0.602 \pm 0.009^{\#}$ & $0.57 \pm 0.03$ \\
Metformin & $44.26 \pm 1.31^{* \#}$ & $25.47 \pm 0.77^{* \#}$ & $19.44 \pm 0.53^{* \#}$ & $0.618 \pm 0.006$ & $0.44 \pm 0.02^{*}$ \\
R20 & $31.40 \pm 1.04^{* \#}$ & $20.66 \pm 0.67^{* \#}$ & $15.44 \pm 0.34^{\#}$ & $0.637 \pm 0.001^{*}$ & $0.50 \pm 0.02$ \\
R40 & $38.97 \pm 0.84^{* \#}$ & $25.31 \pm 0.42^{* \#}$ & $16.80 \pm 0.41^{\#}$ & $0.639 \pm 0.007^{*}$ & $0.43 \pm 0.01^{*}$ \\
\hline *Significantly differt from HFHF contro \# & & &
\end{tabular}

*Significantly different from HFHF control, ${ }^{\#}$ significantly different from normal control at $\mathrm{p}<0.05$.

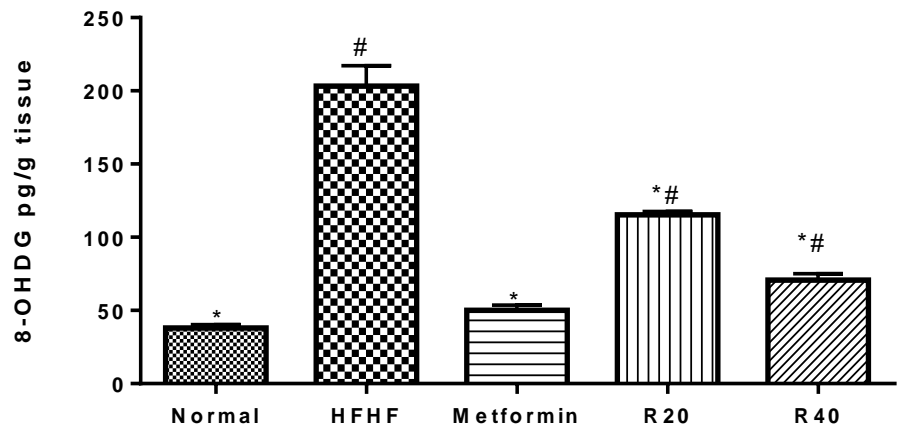

Fig. 3: Effects of RSV on liver tissue 8-OHDG content in rats with HFHF diet-induced IR. *Significantly different from HFHF control, \# significantly different from normal control at $p<0.05$.

\section{Effects of RSV on liver tissue cell energy in rats with HFHF diet-induced IR}

HFHF resulted in significant reduction in the cell energy represented by the lowered ATP, ADP and AMP, AEC levels and increased AMP/ATP ratio as compared to the normal control. RSV at its two dose levels (20 and $40 \mathrm{mg} / \mathrm{kg}$ ) and metformin significantly elevated the cell energy parameters as compared to the HFHF control at $\mathrm{p}<0.05$ where the overall results of resveratrol (40 mg/kg) were prominent over metformin (Table 4).

\section{Effects of RSV on liver tissue 8-OHDG content in rats with HFHF diet-induced IR}

HFHF resulted in significant elevation in 8-OHDG content in the liver tissue suggesting severe tissue damage and DNA fragmentation $(203.3 \pm 13.85$ vs. $38.1 \pm 2.22 \mathrm{pg} / \mathrm{g})$ as compared to normal control. RSV(20 and $40 \mathrm{mg} / \mathrm{kg})$ treatment significantly reduced the 8-OHDG level $(115.3 \pm 2.23$ and $70.81 \pm$ 4.26 vs. $203.3 \pm 13.85 \mathrm{pg} / \mathrm{g}$ ) respectively as compared to the HFHF control and the results were comparable to those of metformin. (Figure 3).

\section{DISCUSSION}

Insulin resistance (IR), the hallmark of MetS, is a metabolic condition in which the cells do not use insulin properly and as the need for insulin rises and the pancreas gradually loses its ability to produce it; the condition usually leads to type 2 diabetes mellitus (T2DM) (Kozono et al., 2016). It is usually characterized by the impairment of glucose uptake in muscle and the elevation of endogenous glucose production by the liver resulting in hyperglycemia. IR is accompanied with severe liver damage with abnormal liver enzymes levels and hepatic inflammation (Mellendijk et al., 2015).

High fat-high fructose diet (HFHF) is now considered as a well-established model for the induction of IR in rodents (Wang et al., 2015a, Zhang et al., 2016, Zhuhua et al., 2015). In 
accordance with previous studies (Afifi et al., 2016, Lozano et al., 2016), the present study confirms the relationship between HFHF diet-induced IR model in rats and its impact on hepatic tissue such as hepatic steatosis complicated by fibrosis, inflammation, and oxidative stress.

In our study; adding high fat in the diet and high fructose in the drinking water of rats was associated with a marked increase in body weight and HOMA-IR indicating the development of insulin resistance in rats. Moreover; the model lead to amplification in HAIR and LAIR expression in liver tissue, significant increase in serum liver functions viz. ALT and AST, as well as liver tissue TC and TG levels, decrease in serum total protein and albumin levels along with liver tissue marked oxidative and nitrosative stresses, elevation in liver tissue TNF- $\alpha$ level, liver tissue DNA fragmentation as demonstrated by the elevated 8-OHDG level and severe reduction in liver tissue cell energy represented by lowered adenylate energy charge (AEC) level and increased AMP/ATP ratio; all of which are markers of hepatic injury.

Hepatocytes have a complicated system of enzymatic and non-enzymatic antioxidant defenses to neutralize reactive oxygen and nitrogen species (ROS) and (RNS). However, increased levels of ROS and RNS may overcome the hepatocellular antioxidant defense mechanism, resulting in hepatocyte injury and inducing hepatic steatosis which subsequently end with cell death (Lozano et al., 2016).Liver in an insulin-dependent tissue and plays a vital role in glucose and lipid homeostasis (Sivajothi et al., 2007). High fasting blood glucose level is considered as a stamp characteristic of IR resulting from loss of insulin sensitivity in its target tissues(Reddy et al., 2016). Fluctuating levels of AST and ALT are mostly the result of the leakage of these enzymes from the cytosol of hepatocytes into the blood stream. However, increased levels of these enzymes may result in low levels of serum albumin and total protein that are used as indicators of liver functions.A decrease in serum albumin and total protein levels may contribute to the inhibition of oxidative phosphorylation process, leading to a reduction in protein absorption, a decline in protein synthesis, and an increase in the catabolic process (Ghanbari et al., 2016).

Furthermore, our results are in accordance with the twohits hypothesis described by Day and James (Day,James, 1998), in which the accumulation of hepatic TG constitutes the first hit of NASH pathogenesis, and oxidative stress followed by inflammation which represents the second hit. The development of hepatic steatosis via accumulation of TG in hepatocytes increases the vulnerability of the liver to inflammation, fibrosis, and cellular death representing hallmarks of NASH.

In addition; it has been shown that obesity in rodents resulted in an increase in macrophages in adipose tissue due to an increased infiltration and/or proliferation of cells (Mellendijk et al., 2015, Patel et al., 2016). Besides; IR is accompanied with increased numbers of classically activated macrophages in the white adipose tissue producing many pro-inflammatory cytokines like TNF- $\alpha$, IL-1, and IL-6(Mellendijk et al., 2015). IR promotes DNA damage via the induction of oxidative stress (Paneni et al.,
2013).Therefore, antioxidants protect cells against oxidative damage. Decrease in antioxidant defense system is followed by the damage of cellular organelles and enzymes, increased level of lipid peroxidation, and development of IR. Oxidative and nitrosative stresses causing structural and functional alterations in the cellular biomolecules and cell membrane are the result of the development of complications in diabetic individuals(D'Archivio et al., 2012, Fisher-Wellman,Bloomer, 2009, Park et al., 2009). Attack by ROS and RNS leads to DNA hydroxylation; oxidizing DNA to form 8-hydroxy-2-deoxyguanosine (8-OHDG) adducts; a major species of oxidative DNA damage (Aksit,Bildik, 2014). 8-OHDG content is considered a sensitive biomarker of the oxidative DNA damage and repair (Abdelali et al., 2016).

Tissue HAIR and LAIR receptors expression could be used as reliable method of determining the ability of body organs to utilize insulin. Increase in the number of insulin receptors, usually indicates impaired insulin utilization and relates positively with hyper-insulinemia and IR and negatively with insulin sensitivity (Amin et al., 2014).

Finally; tissue ATP, ADP and AMP levels reveal the energetic status of cells. Nowadays; adenylate energy charge (AEC) equation is used to determine the cell energy status (De la Fuente et al., 2014). Diminution of energy insufficiencies designated by elevated ATP and adenylate energy charge levels, and decreased AMP/ATP ratio could be used as consistent markers demonstrating protection against tissue injury (Wang et al., 2015b).

Recently; resveratrol (RSV) has been investigated for the possibility of having anti-hyperglycemic and hepatoprotective actions in several animal models for diabetes as well as clinical studies on diabetic and/or healthy volunteers alone or concomitant with high fat diet regimen, with or without anti-diabetic medications. Yet the results have been so far controversial and the mechanism of action has not been totally clarified (Timmers $e$ t al., 2012, Zeng et al., 2016, Zhao et al., 2016). The main findings were mainly that in some studies RSV improved glycemic control by mechanisms that involve improvement in insulin secretion and activity and sometimes anti-inflammatory and hepatoprotective effects (Pektas et al., 2016, Yonamine et al., 2016, Zare Javid et al., 2016). In the present study, we focused on the effect of RSV on hepatic tissue cells energy state along with the ability to maintain cells integrity by prevention of cellular DNA fragmentation and improvement of the liver tissue ability to utilize insulin. Results of the study revealed improvement in IR and the concomitant liver ability to utilize insulin which was represented by reduced HOMA-IR as well as decreased liver HAIR and LAIR expression. Enhancement of liver performance in addition to amelioration in liver tissue damage were also detected through serum and tissue liver functions, inflammatory, DNA fragmentation and cell energy biomarkers signified by reduced ALT, AST, TC and TG levels and increased albumin and total protein levels, decreased TNF- $\alpha$, 8-OHDG contents, elevated adenylate energy charge (AEC) along with lowered AMP/ATP ratio.Hepatic oxidative and nitrosative stresses also declined. The 
overall results were comparable to those of metformin indicating the beneficial effects of using RSV in IR.

\section{CONCLUSION}

Using RSV as daily supplement could be advantageous in ameliorating hepatic insult associated with IR in MetS. The mechanism of action of RSV possibly involves restoration of cell energy, preservation of cell integrity and prevention of DNA fragmentation.

\section{FUNDING SOURCE}

The research was funded by National Research Centre; project No. P100519.

\section{CONFLICTS OF INTEREST}

The authors declare there were no conflicts of interest

\section{REFERENCES}

Abdelali A, Al-Bader M, Kilarkaje N. Effects of TransResveratrol on hyperglycemia-induced abnormal spermatogenesis, DNA damage and alterations in poly (ADP-ribose) polymerase signaling in rat testis. Toxicol Appl Pharmacol, 2016; 311: 61-73.

Afifi NA, Ramadan A, Erian EY, Saleh DO, Sedik AA, Badawi M, El Hotaby W. Trigonelline attenuates hepatic complications and molecular alterations in high-fat high-fructose diet-induced insulin resistance in rats. Can J Physiol Pharmacol, 2016: 1-10.

Aksit $\mathrm{H}$, Bildik A. Determination of DNA damage in experimental liver intoxication and role of $\mathrm{N}$-acetyl cysteine. Cell Biochem Biophys, 2014; 70: 1119-25.

Amin MM, Asaad GF, Abdel Salam RM, El-Abhar HS, Arbid MS. Novel CoQ10 antidiabetic mechanisms underlie its positive effect: modulation of insulin and adiponectine receptors, Tyrosine kinase, PI3K, glucose transporters, sRAGE and visfatin in insulin resistant/diabetic rats. PLoS One, 2014; 9: e89169.

Atkinson DE, Walton GM. Adenosine triphosphate conservation in metabolic regulation. Rat liver citrate cleavage enzyme. J Biol Chem, 1967; 242: 3239-41.

Axelsen LN, Pedersen HD, Petersen JS, Holstein-Rathlou NH, Kjolbye AL. Metabolic and cardiac changes in high cholesterol-fructosefed rats. J Pharmacol Toxicol Methods, 2010; 61: 292-6.

Balistreri CR, Caruso C, Candore G. The role of adipose tissue and adipokines in obesity-related inflammatory diseases. Mediators Inflamm, 2010; 2010: 802078.

Bonavida B. Immunomodulatory effect of tumor necrosis factor. Biotherapy, 1991; 3: 127-33.

Bremer AA. Resveratrol use in metabolic syndrome. Metab Syndr Relat Disord, 2014; 12: 493-5.

Bugianesi E, Moscatiello S, Ciaravella MF, Marchesini G. Insulin resistance in nonalcoholic fatty liver disease. Curr Pharm Des, 2010; 16: 1941-51.

Bulaj G, Kortemme T, Goldenberg DP. Ionization-reactivity relationships for cysteine thiols in polypeptides. Biochemistry, 1998; 37: 8965-72.

Chen WM, Shaw LH, Chang PJ, Tung SY, Chang TS, Shen $\mathrm{CH}$, Hsieh YY, Wei KL. Hepatoprotective effect of resveratrol against ethanol-induced oxidative stress through induction of superoxide dismutase in vivo and in vitro. Exp Ther Med, 2016; 11: 1231-38.

Corin RE, Donner DB. Insulin receptors convert to a higher affinity state subsequent to hormone binding. A two-state model for the insulin receptor. J Biol Chem, 1982; 257: 104-10.
D'Archivio M, Annuzzi G, Vari R, Filesi C, Giacco R, Scazzocchio B, Santangelo C, Giovannini C, Rivellese AA, Masella R. Predominant role of obesity/insulin resistance in oxidative stress development. Eur J Clin Invest, 2012; 42: 70-8.

Day CP, James OF. Steatohepatitis: a tale of two "hits"? Gastroenterology, 1998; 114: 842-5.

De la Fuente IM, Cortes JM, Valero E, Desroches M, Rodrigues S, Malaina I, Martinez L. On the dynamics of the adenylate energy system: homeorhesis vs homeostasis. PLoS One, 2014; 9: e108676.

Doumas BT, Watson WA, Biggs HG. Albumin standards and the measurement of serum albumin with bromcresol green. Clin Chim Acta, 1971; 31: 87-96. 1959; 82: 70-7.

Ellman GL. Tissue sulfhydryl groups. Arch Biochem Biophys,

Fassati P, Principe L. Measurement of serum triglyceride colorimetrically with an enzyme that produce H2O2. Clin Chem, 1982; 28: 2077-80.

Fisher-Wellman K, Bloomer RJ. Macronutrient specific postprandial oxidative stress: relevance to the development of insulin resistance. Curr Diabetes Rev, 2009; 5: 228-38.

Ghanbari E, Nejati V, Khazaei M. Improvement in Serum Biochemical Alterations and Oxidative Stress of Liver and Pancreas following Use of Royal Jelly in Streptozotocin-Induced Diabetic Rats. Cell J, 2016; 18: 362-70.

Gornall AG, Bardawill CJ, David MM. Determination of serum proteins by means of the biuret reaction. J Biol Chem, 1949; 177: 751-66.

Grassi J, Pradelles P, 1991. Compounds labelled by the acetylcholinesterase of Electrophorus Electricus. Its preparation process and its use as a tracer or marquer in enzymo-immunological determinations. US Patent N1,047,330.

Kozono M, Uto H, Ibusuki R, Arima S, Oda K, Taguchi H, Sasaki F, Nasu Y, Hashimoto S, Setoyama H, Kanmura S, Numata M, Tsubouchi H, Ido A. Antihypertensive therapy improves insulin resistance and serum levels of interleukin-6 and -10 in spontaneously hypertensive rats with steatohepatitis. Mol Med Rep, 2016; 14: 5385-94.

Liaw JJ, Peplow PV. Effect of Electroacupuncture on Inflammation in the Obese Zucker Fatty Rat Model of Metabolic Syndrome. J Acupunct Meridian Stud, 2016; 9: 73-9.

Liu H, Jiang Y, Luo Y, Jiang W. A Simple and Rapid Determination of ATP, ADP and AMP Concentrations in Pericarp Tissue of Litchi Fruit by High Performance Liquid Chromatography. Food Technology and Biotechnology, 2006; 44: 531-34.

Lodovici M, Casalini C, Briani C, Dolara P. Oxidative liver DNA damage in rats treated with pesticide mixtures. Toxicology, 1997; 117: 55-60.

Lozano I, Van der Werf R, Bietiger W, Seyfritz E, Peronet C, Pinget M, Jeandidier N, Maillard E, Marchioni E, Sigrist S, Dal S. Highfructose and high-fat diet-induced disorders in rats: impact on diabetes risk, hepatic and vascular complications. Nutr Metab (Lond), 2016; 13: 15.

Maithili Karpaga Selvi N, Sridhar MG, Swaminathan RP, Sripradha R. Curcumin Attenuates Oxidative Stress and Activation of Redox-Sensitive Kinases in High Fructose- and High-Fat-Fed Male Wistar Rats. Sci Pharm, 2015; 83: 159-75.

Martinez-Abundis E, Mendez-Del Villar M, Perez-Rubio KG, Zuniga LY, Cortez-Navarrete M, Ramirez-Rodriguez A, Gonzalez-Ortiz M. Novel nutraceutic therapies for the treatment of metabolic syndrome. World J Diabetes, 2016; 7 : 142-52.

Matthews DR, Hosker JP, Rudenski AS, Naylor BA, Treacher DF, Turner RC. Homeostasis model assessment: insulin resistance and beta-cell function from fasting plasma glucose and insulin concentrations in man. Diabetologia, 1985; 28: 412-9.

Mellendijk L, Wiesmann M, Kiliaan AJ. Impact of Nutrition on Cerebral Circulation and Cognition in the Metabolic Syndrome. Nutrients, 2015; 7: 9416-39.

Miranda KM, Espey MG, Wink DA. A rapid, simple spectrophotometric method for simultaneous detection of nitrate and nitrite. Nitric Oxide, 2001; 5: 62-71. 
Morsy MA, Ibrahim MA, Abd-Elghany MI. Dimethyl dimethoxy biphenyl dicarboxylate attenuates hepatic and metabolic alterations in high fructose-fed rats. Toxicol Ind Health, 2016; 32: 59-67.

Narasimhan A, Chinnaiyan M, Karundevi B. Ferulic acid exerts its antidiabetic effect by modulating insulin-signalling molecules in the liver of high-fat diet and fructose-induced type-2 diabetic adult male rat. Appl Physiol Nutr Metab, 2015; 40: 769-81.

Paneni F, Beckman JA, Creager MA, Cosentino F. Diabetes and vascular disease: pathophysiology, clinical consequences, and medical therapy: part I. Eur Heart J, 2013; 34: 2436-43.

Park K, Gross M, Lee DH, Holvoet P, Himes JH, Shikany JM, Jacobs DR, Jr. Oxidative stress and insulin resistance: the coronary artery risk development in young adults study. Diabetes Care, 2009; 32: 1302-7.

Patel TP, Rawal K, Bagchi AK, Akolkar G, Bernardes N, Dias Dda S, Gupta S, Singal PK. Insulin resistance: an additional risk factor in the pathogenesis of cardiovascular disease in type 2 diabetes. Heart Fail Rev, 2016; 21: 11-23.

Pektas MB, Sadi G, Koca HB, Yuksel Y, Vurmaz A, Koca T, Tosun M. Resveratrol Ameliorates the Components of Hepatic Inflammation and Apoptosis in a Rat Model of Streptozotocin-Induced Diabetes. Drug Dev Res, 2016; 77: 12-9.

Peredo-Escarcega AE, Guarner-Lans V, Perez-Torres I, OrtegaOcampo S, Carreon-Torres E, Castrejon-Tellez V, Diaz-Diaz E, RubioRuiz ME. The Combination of Resveratrol and Quercetin Attenuates Metabolic Syndrome in Rats by Modifying the Serum Fatty Acid Composition and by Upregulating SIRT 1 and SIRT 2 Expression in White Adipose Tissue. Evid Based Complement Alternat Med, 2015; 2015: 474032

Radwan O, Ahmed RF. Amendment effect of resveratrol on diclofenac idiosyncratic toxicity: Augmentation of the anti-inflammatory effect by assessment of Arachidonic acid and IL-1beta levels. Journal of Applied Pharmaceutical Science, 2016; 6: 170-77.

Reddy BR, Maitra S, Jhelum P, Kumar KP, Bagul PK, Kaur G, Banerjee SK, Kumar A, Chakravarty S. Sirtuin 1 and 7 mediate resveratrol-induced recovery from hyper-anxiety in high-fructose-fed prediabetic rats. J Biosci, 2016; 41: 407-17.

Reitman S, Frankel S. A colorimetric method for the determination of serum glutamic oxalacetic and glutamic pyruvic transaminases. Am J Clin Pathol, 1957; 28: 56-63.

Richmond W. Preparation and properties of a cholesterol oxidase from Nocardia sp. and its application to the enzymatic assay of total cholesterol in serum. Clinical chemistry, 1973; 19: 1350-56.

Rodriguez Lanzi C, Perdicaro DJ, Antoniolli A, Fontana AR, Miatello RM, Bottini R, Vazquez Prieto MA. Grape pomace and grape pomace extract improve insulin signaling in high-fat-fructose fed ratinduced metabolic syndrome. Food Funct, 2016; 7: 1544-53.

Ruiz-Larrea MB, Leal AM, Liza M, Lacort M, de Groot $\mathrm{H}$. Antioxidant effects of estradiol and 2-hydroxyestradiol on iron-induced lipid peroxidation of rat liver microsomes. Steroids, 1994; 59: 383-8.

Sicinska P, Pytel E, Macczak A, Koter-Michalak M. [The use of various diet supplements in metabolic syndrome]. Postepy Hig Med Dosw (Online), 2015; 69: 25-33.

Sivajothi V, Dey A, Jayakar B, Rajkapoor B. Antihyperglycemic property of Tragia cannabina in streptozotocin-induced diabetic rats. J Med Food, 2007; 10: 361-5.
Teerlink T, Hennekes M, Bussemaker J, Groeneveld J. Simultaneous determination of creatine compounds and adenine nucleotides in myocardial tissue by high-performance liquid chromatography. Anal Biochem, 1993; 214: 278-83.

Timmers S, Auwerx J, Schrauwen P. The journey of resveratrol from yeast to human. Aging (Albany NY), 2012; 4: 146-58.

Trinder P. Determination of blood glucose using an oxidaseperoxidase system with a non-carcinogenic chromogen. J Clin Pathol, 1969; 22: 158-61.

Vallianou NG, Evangelopoulos A, Kazazis C. Resveratrol and diabetes. Rev Diabet Stud, 2013; 10: 236-42.

Wang O, Liu J, Cheng Q, Guo X, Wang Y, Zhao L, Zhou F, Ji B. Effects of ferulic acid and gamma-oryzanol on high-fat and highfructose diet-induced metabolic syndrome in rats. PLoS One, 2015a; 10: e0118135.

Wang X, Liu Y, Li S, Pi D, Zhu H, Hou Y, Shi H, Leng W. Asparagine attenuates intestinal injury, improves energy status and inhibits AMP-activated protein kinase signalling pathways in weaned piglets challenged with Escherichia coli lipopolysaccharide. Br J Nutr, 2015b; 114: 553-65.

Yonamine CY, Pinheiro-Machado E, Michalani ML, Freitas HS, Okamoto MM, Correa-Giannella ML, Machado UF. Resveratrol improves glycemic control in insulin-treated diabetic rats: participation of the hepatic territory. Nutr Metab (Lond), 2016; 13: 44

Zare Javid A, Hormoznejad R, Yousefimanesh HA, Zakerkish M, Haghighi-Zadeh MH, Dehghan P, Ravanbakhsh M. The Impact of Resveratrol Supplementation on Blood Glucose, Insulin, Insulin Resistance, Triglyceride, and Periodontal Markers in Type 2 Diabetic Patients with Chronic Periodontitis. Phytother Res, 2016.

Zeng K, Wang Y, Yang N, Wang D, Li S, Ming J, Wang J, Yu X, Song Y, Zhou X, Deng B, Wu X, Huang L, Yang Y. Resveratrol Inhibits Diabetic-Induced Muller Cells Apoptosis through MicroRNA29b/Specificity Protein 1 Pathway. Mol Neurobiol, 2016.

Zhang J, Wang O, Guo Y, Wang T, Wang S, Li G, Ji B, Deng Q. Effect of Increasing Doses of Linoleic and alpha-Linolenic Acids on High-Fructose and High-Fat Diet Induced Metabolic Syndrome in Rats. J Agric Food Chem, 2016; 64: 762-72.

Zhao W, Li A, Feng X, Hou T, Liu K, Liu B, Zhang N. Metformin and resveratrol ameliorate muscle insulin resistance through preventing lipolysis and inflammation in hypoxic adipose tissue. Cell Signal, 2016; 28: 1401-11.

Zhuhua Z, Zhiquan W, Zhen Y, Yixin N, Weiwei Z, Xiaoyong L, Yueming L, Hongmei Z, Li Q, Qing S. A novel mice model of metabolic syndrome: the high-fat-high-fructose diet-fed ICR mice. Exp Anim, 2015; 64: 435-42.

\section{How to cite this article:}

Saleh DO, Awdan SAE, Jaleel GAA, Ahmed RF. Resveratrol attenuates hepatic complications associated with insulin resistance: Implications on hepatic HAIR, LAIR, cell energy and DNA fragmentation. J App Pharm Sci, 2017; 7 (08): 020-027. 